\title{
How the Euro divides the union: the effect of economic adjustment on support for democracy in Europe
}

\author{
Klaus Armingeon*, Kai Guthmann, and David Weisstanner \\ University of Bern, Bern, Switzerland \\ *Correspondence: klaus.armingeon@ipw.unibe.ch
}

\begin{abstract}
As often pointed out in the literature on the European debt crisis, the policy programme of austerity and internal devaluation imposed on countries in the Eurozone's periphery exhibits a lack of democratic legitimacy. This article analyses the consequences these developments have for democratic support at both the European and national levels. We show that through the policies of economic adjustment, a majority of citizens in crisis countries has become 'detached' from their democratic political system. By cutting loose the Eurozone's periphery from the rest of Europe in terms of democratic legitimacy, the Euro has divided the union, instead of uniting it as foreseen by its architects. Our results are based on aggregated Eurobarometer surveys conducted in 28 European Union (EU) member states between 2002 and 2014. We employ quantitative time-series cross-sectional regression analyses. Moreover, we estimate the causal effect of economic adjustment in a comparative case study of four cases using the synthetic control method.
\end{abstract}

Key words: Eurozone, Great Recession, democratic legitimacy, democratic support

JEL classification: J18 Public Policy, E65 Studies of Particular Policy Episodes, P16 Political Economy

\section{Introduction}

The 'Great Recession' that started in 2008 in the USA evolved into a crisis of the European monetary union since 2010. Among the current 19 countries that make up the Eurozone, the first to be bailed out by its European Union (EU) partners and the IMF was Greece in 2010, followed by Ireland and Portugal in 2011 and Cyprus in 2013. Spain entered a programme to recapitalize its banking sector in 2012, and Italy has been under informal conditionality (Sacchi, 2015). When the EU, in collaboration with the IMF, requested painful austerity and structural reform policies in return for financial support, the respective national 
governments had little choice but to accept. Consequently, voters experienced that it did not matter who was in government and that the preferences of a majority of the citizens would not be translated into policies.

What are the consequences of economic adjustment programmes during the Euro-crisis for the attitudes of citizens towards their democratic political system both at the European and national level? This is our guiding question.

We develop an argument for which we provide empirical evidence in a re-analysis of 26 aggregated Eurobarometer surveys between 2002 and 2014. This argument starts with the observation that membership in the Eurozone severely limits policy choices for the crisis countries struggling with balance-of-payments deficits. Most importantly, having abandoned their national currencies, these countries cannot take recourse to exchange rate devaluation as a convenient means to restore international competitiveness. Rather, they are forced to engineer an internal devaluation and implement a massive austerity programme in the midst of a recession. That is, countries must indulge in the difficult task of improving competitiveness and stimulating exports by reducing sticky domestic wages and prices. Being forced to adhere to strict conditionalities attached to financial assistance, voters in these countries are likely to conclude that their democracy is pre-empted. In other words, the policies of internal devaluation and austerity pursued in the Eurozone's periphery exhibit a lack of democratic legitimacy, both with respect to the output-oriented dimension (for their devastating immediate social consequences) and the input-oriented dimension of democratic legitimacy (Scharpf, $2013 a, b, c)$.

This loss of legitimacy translates into a broad-based erosion of support for the democratic political system both at the national and European level. We demonstrate that externally imposed policies of internal devaluation are associated with an increase in the proportion of the population that simultaneously evaluates the democratic political system at both levels in a negative light. We label this group of citizens as being 'detached' from their democratic political system. Our focus on the 'detached' owes to the observation that this group has, in the affected countries, grown to become the largest over the course of the crisis.

In connection with recent literature on the political-institutional roots of the crisis, our argument has some broader implications. According to this literature (De Grauwe, 2012, 2013; Hall, 2012; Hancké, 2013; Scharpf, 2013a,b,c; Höpner and Lutter, 2014; Johnston et al., 2014), the Euro-crisis should be interpreted as the outcome of institutionally too heterogeneous countries entering a currency union that was ill-equipped to prevent them from diverging economically. From the perspective of economic theory, the Eurozone does not resemble an optimal currency area (OCA).

In other words, the Euro-crisis has to a substantial degree been a crisis of its own making. By forcefully determining the painful policy response pursued by deficit countries, the Euro itself may be held accountable for democratic deficits and detachment in the periphery. We therefore argue that instead of uniting Europe, as foreseen by the architects of monetary union, the Euro currently divides the peoples of Europe with respect to their attitudes towards their democratic political system. It cuts off the Eurozone's periphery from the rest of the continent in terms of democratic legitimacy, puts up creditor against debtor nations, surplus against deficit countries and has become a major source of conflict and disintegration among the peoples of the EU and their increasingly populist representatives in the political arena (also see Streeck and Elsässer, 2014; Streeck, 2015). 
The empirical section of this article has three components. First, we examine the development of support for democratic political systems at the national and the European level descriptively. Next, we estimate in a large- $\mathrm{N}$ time-series cross-sectional regression analysis if variances in support can be explained by externally imposed internal devaluation policies. Finally, we examine this effect of economic adjustment in a small-N comparative case study of four cases (Greece, Latvia, Germany and Sweden) using the synthetic control method.

\section{The argument}

When the heads of European governments signed the treaty of Maastricht in February 1992, they created a currency union (Economic and Monetary Union, EMU) that was meant to unite the peoples of Europe, not only economically, but also politically, by strengthening the European identity. Learning from past experience with various European regimes of fixed exchange rates since Bretton Woods (see Eichengreen, 2008 for an overview), they realized that successful operation of a monetary union would require the trends of certain economic variables to become harmonized. Divergent wages and prices had to be prevented from driving the economies of the union apart. The logic behind this is that in the absence of exchange rates, such divergences in relative prices translate, when not corrected immediately, into divergent labour and production costs. These, in turn, tend to erode the competitiveness of aboveaverage inflation countries, and bolster that of countries with below-average wage and price inflation.

With the introduction of the Euro in 1999, national monetary policies were handed over to the European Central Bank (ECB), obliged by law to ensure price stability across the Eurozone. Fiscal rectitude was enshrined in the criteria of the Stability and Growth Pact (SGP). In line with at-the-time dominant monetarist thinking in the circles of the European commission (De Grauwe, 2013, p. 157), with these two (i.e. monetary and fiscal policy) critical sources of disturbances to national wages and prices neutralized, monetary union was supposed to work.

More critical voices to this position, such as from thinkers questioning whether the Eurozone was an OCA, were by and large neglected (Hall, 2012; De Grauwe, 2013). An OCA exhibits a high degree of labour and capital mobility and wage-price flexibility (Mundell, 1961). This facilitates smooth re-adjustment when national price levels have for some reason started to diverge. If labour mobility and wage-price flexibility are limited, a system of fiscal transfers should support uncompetitive regions, especially when the union is hit by an asymmetric shock. The Eurozone has turned out to fare rather poorly on all these criteria (De Grauwe, 2013).

Most crucially in retrospect, however, the architects of EMU failed to honour early warnings (such as from Scharpf, 1986), that the Europeanization of monetary and fiscal policy would not suffice to ensure convergence of national wage and price dynamics. Rather, inflation divergences are also driven by institutional differences across countries, especially in the fields of industrial relations and collective bargaining (see, e.g. Fleming, 1971)—an aspect that has arguably been highly relevant for the institutionally heterogeneous members of the Eurozone (Höpner and Lutter, 2014).

Beginning with the introduction of the Euro in 1999, relative wages and prices have indeed diverged markedly across the members of the union, thereby building up substantial macroeconomic imbalances (Hall, 2012). At the outset of the Great Recession, these were reflected in 
years of above-average wage and price inflation in the South, but below-average inflation in the North, translating into eroding international competitiveness and persistent trade deficits in the South, but strong export growth and surpluses in the North, and thus eventually created net debtors in the South and net creditors in the North. This build-up of macroeconomic imbalances in the run-up to the crisis has considerably increased deficit countries' vulnerability to external shocks.

When such a shock swept over the Atlantic under the guise of the global financial crisis, it hit them at their respective Achilles heals and led to skyrocketing budget deficits and debts (Armingeon and Baccaro, 2012). Spain and Ireland, for instance, had shown an extraordinary growth performance and recorded consistent budget surpluses in the past, but that was primarily achieved through an overheated property market and overextended banking sector. Portugal suffered from anaemic growth in a weakly modernized economy, and so did Greece. The latter also had to cope with a wasteful and inefficient public sector. In contrast, export-oriented and highly competitive economies, such as Germany, benefitted from the opportunities offered by EMU membership both before and during the Great Recession. When the crisis hit, these countries were considered 'safe havens' for investors and therefore benefited from extremely low interest rates on their sovereign bonds (Leibniz-Institut für Wirtschaftsforschung Halle (IWH), 2015).

Some governments in the North were quick to extrapolate the diagnosis of fiscal profligacy in Greece to other Mediterranean countries, and called for fiscal prudence and structural reforms. The German chancellor, Angela Merkel, framed the situation as one of delayed 'homework', which Germany had foresightedly completed by liberalizing its labour market with the 'Hartz-reforms' in 2002-2005.

In contrast, a growing number of economists and social scientists have interpreted the crisis as the outcome of institutionally heterogeneous countries entering a currency union that does not resemble an OCA, and thereby strongly contributing to the emergence of macroeconomic imbalances as described above (De Grauwe, 2012, 2013; Hall, 2012; Scharpf, 2013b,c; Höpner and Lutter, 2014). Other authors have taken an even broader perspective in analysing the crisis from regulationist and post-Keynesian viewpoints (see, e.g. Becker and Jäger, 2012; Boyer, 2013; Hein, 2013). Most relevant to our argument, in the words of Peter Hall (2012, p. 355), 'the roots of the crisis [lie] in an institutional asymmetry grounded in national varieties of capitalism, which saw political economies organized to operate export-led growth models joined to others accustomed to demand-led growth.' Similarly, Hancké (2013) interprets the Euro-crisis mainly as a competitiveness crisis, which can be traced back to systematic differences between wage-setting regimes in the Eurozone's core and those in the periphery. Finally, Johnston et al. (2014) put both the 'fiscal profligacy' and the 'competitiveness' interpretation to the test, and provide empirical evidence that countries' varying exposure to bond market pressure at the height of the sovereign debt crisis can be explained by competitiveness imbalances. These, in turn, originate in large part from the availability of corporatist institutions, working as a comparative institutional advantage to limit wage growth in the export sector. In other words, what comes disguised as the European sovereign debt crisis has important institutional roots in the heterogeneous varieties of capitalism bound together in the Eurozone. In sum, during its first decade the Euro has, owing to its weak institutional foundations, driven the Eurozone apart economically and contributed to the severity of the crisis.

A more crucial implication of membership in this non-OCA is that it also deprives countries of traditional macroeconomic policy instruments for crisis response and resolution. 
Among these are autonomous monetary and fiscal policies to fight recessions and unemployment with some form of Keynesian demand stimulus. Most relevant in the context of this article, however, is it deprives Eurozone deficit countries of the single most effective tool to deal with macroeconomic imbalances: an independent exchange rate policy to carry out an (external) currency devaluation that restores export competitiveness in one stroke, and thereby works to correct imbalances. Instead, irrespective of their institutional heterogeneity and political traditions, EMU membership forces upon these countries a common response: an economic adjustment programme of internal devaluation and austerity in combination with far-reaching supply-side reforms (Armingeon and Baccaro, 2012). In this sense, these policies are 'externally imposed'. In the absence of substantial fiscal transfers from the outside or more reflationary policies in surplus countries (see, e.g. Stockhammer, 2011), the deficit countries must - at least as long as they wish to comply with the demands of their lenders, honour their debt obligations and ultimately stay in the Eurozone-correct their external imbalances through an internal adjustment of domestic prices and labour costs. ${ }^{1}$ That is, in order to bring about declining wages and prices, they have to deflate their economies without much regard to the economic and social consequences (on the considerable economic costs of internal devaluation see, e.g. Stockhammer and Sotiropoulos, 2014). In order to correct the external imbalance, the internal balance (which aims at low unemployment and stable prices) must be sacrificed. In the short term, this inevitably implies a deepening recession and sharply rising unemployment, usually accompanied by mass protests, strikes and potentially even civil unrest. From an economic point of view, internal and external balance come into conflictsomething that has been a recurring feature in the history of fixed exchange rate arrangements from the gold standard of the interwar period to the EMU of today (Eichengreen, 2008).

What does this mean for democracy? We start from a basic insight famously expressed by Lincoln in his Gettysburg address of November 1863: democracy is not only government by and through the people - the input-side of democracy_but also for the people, i.e. the output of the democratic system must serve the people as well. Therefore, any democracy has to meet the criterion that the people can effectively decide on the course of public policy and that the policy enacted by the legislative branch is in the interest of a broad majority of the people. With respect to the second criterion, then, for the immediate economic and social costs of the recessionary policy package imposed on the deficit countries in the periphery, the output-oriented dimension of democratic legitimacy is damaged. Democratic governments delivered policies that implied welfare state retrenchment, an erosion of the protective rules for particularly vulnerable parts of the citizenry (such as employment protection legislation for temporary workers) and initially tended to exacerbate, rather than to mitigate, economic and social hardships. With respect to the first criterion: democracy is about choice-but in the current economic and political configuration of this non-OCA, no other option is left for deficit countries but to implement those policies of internal devaluation. Greece in July

1 Some of these policies may be actively supported by government and parliament, in particular if the latter are not otherwise forced to implement them. In particular, this applies to countries outside the Eurozone. For EMU members, however, internal devaluation ultimately is independent of the stance of national government, as is nicely illustrated by the Greek case in summer 2015. If a country does not meet the fiscal benchmarks and cannot (re-)negotiate a more gradual path of adjustment with its international lenders, there is no feasible alternative to internal devaluation. Its room of manoeuvre is severely constrained. 
2015 offers the clearest example for this lack of input legitimacy, when the government was forced to accept reforms which the majority of the people had rejected in a popular vote only a week before. Consequently, if the people are deprived of their choice, the input-oriented dimension of democratic legitimacy is damaged as well. Taken together, the economic adjustment programmes of internal devaluation-cum-austerity imposed on deficit countries lack democratic legitimacy with respect to both the output and the input dimension of the democratic process (Scharpf, 2013a,b,c).

Starting from a somewhat higher level of theoretical abstraction, Streeck $(2014$, p. 116) describes this whole situation, and its underlying causes, using the term of a 'European consolidation state' as a multilevel regime with the purpose of de-politicizing the economy while simultaneously de-democratizing politics. Likewise, researchers in the tradition of Antonio Gramsci speak of a 'bureaucratic Caesarism' being the 'reinforcement of judicial economic norms and the competence of non-elected European institutions on economic issue' which contributes to a 'de-embeddedness of economic policies from popular influence' (Keucheyan and Durand, 2015, p. 45). In this new EU level regime, financial capital became hegemonic, excluding labour in particular, and preventing state-like democratic institutions (Durand and Keucheyan, 2015), thereby establishing an 'authoritarian neo-liberalism' (Bruff, 2014).

We do not even need to fully agree with such quite far-reaching interpretations, in order to argue, as we do in this article, that this loss of legitimacy in deficit countries translates into an erosion of support for the democratic political system both at the national and the European level, since actors from both levels are likely to be held accountable for the policies of economic adjustment. In consequence, the proportion of the population that has become 'detached' from the democratic political system as a whole (i.e. with respect to both the national and EU level) should rise in the affected countries.

Note that this deficit of democratic legitimacy and concomitant loss of support should by and large be confined to the Eurozone's deficit countries implementing economic adjustment programmes (most prominently Greece, Portugal, Spain, Cyprus, and, with some reservations, Ireland and Italy).

When a similar country outside of the Eurozone is hit by a similar economic shock, it is likely to choose a less painful policy option (such as currency devaluation/depreciation). Output legitimacy may be better maintained in such a case, as illustrated by the UK, which allowed its currency to depreciate strongly (by about 22\%) in 2007-2009. But even if such a country ends up also treading the painful path of internal devaluation (like Latvia did for various reasons), in which case output legitimacy should be undermined, this scenario ought to differ considerably from that within the Eurozone. The crucial difference is choice. Since alternative strategies are available outside the Eurozone, an internal devaluation tends to reflect the free will of the government. And even if this will does not correspond closely to that of the majority of the people, voters may punish their government on election day and empower a different one that undoes previous policies-perhaps by eventually resorting to the safety valve of currency devaluation. At least the input dimension of democratic legitimacy should therefore be left relatively unscathed, compensating somewhat for the damage done to output legitimacy, and support for democracy (at the national level) may be upheld. Moreover, we have no reason to believe that support for the European level of democracy would suffer when a national government pursues an internal devaluation unilaterally. In the aggregate, 'detachment' should therefore not rise too much. 
Finally, countries without substantial economic woes, no matter whether they are located inside the Eurozone (such as Germany, the Netherlands or Finland), or outside (such as Sweden or Poland), did not implement any adjustment programme that could trigger a noticeable, and bi-dimensional, loss of democratic legitimacy. Thus, 'detachment' should not rise.

In connection with much of the above-cited literature on the roots of the Euro-crisis, our argument implies that the Euro itself divides the peoples of Europe with respect to their attitudes towards their democratic political system. The policies of economic adjustment imposed on deficit countries in order to hold the Eurozone together, cuts them loose from the rest of Europe in terms of democratic legitimacy. Internal devaluation-cum-austerity is creating a whole group of countries where a majority of the population is becoming detached from their democratic political system. In other words, the economic imperatives of monetary union have come into conflict with democracy.

Our argument assumes that citizens are capable of correctly attributing political responsibility. But do citizens actually realize that their democratic system is constrained by external actors and developments? On the one hand, this is not beyond doubt, when considering how limited the political knowledge of European citizens actually is (Hobolt and Leblond, 2014). With respect to EU level developments in particular, there is some evidence that citizens mainly place blame on domestic actors, even if national policies and outcomes are to a substantial degree determined from outside. On the other hand, however, Scharpf (2013a) argues that the citizens of deficit countries in the periphery - and these are most relevant to our argument-know exactly that it was the Troika who imposed those painful policies of economic adjustment. For these countries at least, it seems reasonable that even ordinary citizens cannot escape the messages by the mass media, that the malaise of their country-epitomized by massive layoffs, wage-, pension- and welfare cuts, structural reforms, and the concomitant protests and general strikes - had something to do with the pressure exerted by the EU and international bond markets (Kriesi and Grande, 2015). Along these lines, the Troika-bailouts were usually framed as an issue of constrained national sovereignty in the public debate of those countries (see, e.g. Hope, 2010; O’Malley, 2011; Wise, 2011). Against this background, we have not much doubt that what we academically conceptualize as an erosion of democratic legitimacy was indeed responsible for the severe loss of democratic support we are observing.

Since democratic legitimacy - the acceptance of the democratic government-is hard to measure directly, we follow a large number of analyses which operationalize the extent of legitimacy with an indicator on the satisfaction with the way democracy is working. If this legitimacy is lacking, a crucial precondition for the support of the democratic system is not met. Along these lines, we operationalize changes in support based on affirmative answers to the question(s), whether a respondent is satisfied with the way democracy works at the national as well as the European level, and to the question(s), whether a respondent trusts the national parliament as well as the EU (see Appendix A for details on operationalizations and question wordings). All possible (bivariate) responses to each pair of these questions may be condensed into a four-fold table (see Table 1), reflecting the four different combinations of orientations respondents may possess towards the national and the European democratic political system (see Martinotti and Stefanizzi, 1995; Haller, 1999).

First, there is a group of positively oriented citizens towards both levels of their political system. We call them 'approving'. Second, citizens may support their national system, but evaluate the EU negatively. We label them 'national sovereignist'. A third group may be called 'escapist'. For them, the EU system is superior to their poorly evaluated national 
Table 1. Four types of orientations towards the EU and the national political system

\begin{tabular}{lll}
\hline & $\begin{array}{l}\text { Negative orientation } \\
\text { towards the EU }\end{array}$ & $\begin{array}{l}\text { Positive orientation } \\
\text { towards the EU }\end{array}$ \\
\hline $\begin{array}{l}\text { Positive orientation towards the national political system } \\
\text { Negative orientation towards the national political system }\end{array}$ & $\begin{array}{l}\text { National sovereignist } \\
\text { Detached }\end{array}$ & $\begin{array}{l}\text { Approving } \\
\text { Escapist }\end{array}$ \\
\hline
\end{tabular}

democracy. Finally, the 'detached' are citizens critical of both their national and the European political system.

In the inferential part of our empirical analysis, we will focus exclusively on countryspecific variations in the size of the last group of 'detached' citizens, and relate those to externally imposed policies of internal devaluation. Following our theoretical discussion, we will test the following hypothesis: The stronger an internal devaluation imposed upon a Eurozone deficit country, the larger is the increase in the share of detached citizens.

Before that, however, our descriptive analysis will show how the shares of all four groups have changed over the course of the crisis.

\section{Data}

Our empirical analyses are based on 26 Eurobarometer surveys conducted annually (satisfaction variable) or semi-annually (trust variable) in 28 EU member states during the 2002-2014 period. The dependent variable(s) consist of country-specific aggregates calculated from the respective surveys for each year (or half-year) using post-stratification weights as available from the original source. This yields a dataset which is amenable to simple descriptive, timeseries cross-sectional regression and comparative case study analysis.

We operationalize support based on the question(s), whether a respondent is satisfied with the way democracy works at the national (question 1.1) and European level (question 1.2), and whether she or he trusts the national (question 2.1) and European parliament (question 2.2). From these we construct four variables each (i.e. four based on 1.1 and 1.2, and another four based on 2.1. and 2.2) measuring the proportion of the population in each country that may be conceived of as 'approving', 'national sovereignist', 'escapist' or 'detached' (see Table 1).

The descriptive analysis in the following section traces the development of all eight variables from the pre-crisis period of 2006/2007 up until 2013/2014. These two time points are based on aggregate-level observations using at least two Eurobarometer surveys, thereby averaging-out short-term fluctuations. Our findings are substantially unchanged if we use different time points (e.g. 2012/2013 instead of 2013/2014) or annual instead of biannual data. In the subsequent inferential analyses we focus on the group of detached citizens only. The respective variable operationalizations and model specifications are discussed below.

\section{The divide of Europe in terms of support for democracy}

The following tables summarize the development of all four types of orientations towards democratic political systems in the EU over the course of the crisis. Table 2 is based on satisfaction; Table 3 is based on trust. 
Table 2. Attitude types based on satisfaction with democracy in national country and the EU (in percentage)

\begin{tabular}{|c|c|c|c|c|c|c|c|c|c|c|c|c|}
\hline & \multicolumn{3}{|c|}{ Approving } & \multicolumn{3}{|c|}{ National sovereignist } & \multicolumn{3}{|l|}{ Escapist } & \multicolumn{3}{|l|}{ Detached } \\
\hline & $2006 / 07$ & $2013 / 14$ & Difference & $2006 / 07$ & $2013 / 14$ & Difference & $2006 / 07$ & $2013 / 14$ & Difference & $2006 / 07$ & $2013 / 14$ & Difference \\
\hline Austria & 47.4 & 43.7 & -3.7 & 30.0 & 24.6 & -5.4 & 2.6 & 2.8 & 0.2 & 20.0 & 28.9 & 8.9 \\
\hline Belgium & 60.1 & 57.0 & -3.0 & 7.9 & 10.5 & 2.5 & 9.4 & 6.6 & -2.8 & 22.6 & 25.9 & 3.3 \\
\hline Bulgaria & 28.2 & 18.1 & -10.2 & 6.0 & 1.5 & -4.4 & 46.6 & 47.9 & 1.3 & 19.2 & 32.5 & 13.3 \\
\hline Croatia & 23.9 & 18.8 & -5.1 & 5.1 & 1.7 & -3.4 & 29.3 & 36.5 & 7.2 & 41.8 & 43.0 & 1.3 \\
\hline Cyprus & 52.0 & 24.6 & -27.4 & 10.0 & 4.9 & -5.1 & 14.6 & 10.6 & -4.1 & 23.4 & 60.0 & 36.6 \\
\hline Czech Republic & 55.5 & 36.2 & -19.3 & 2.8 & 4.0 & 1.2 & 14.3 & 16.7 & 2.4 & 27.4 & 43.1 & 15.7 \\
\hline Denmark & 67.2 & 65.6 & -1.6 & 27.1 & 23.2 & -4.0 & 2.0 & 2.8 & 0.8 & 3.7 & 8.4 & 4.7 \\
\hline Estonia & 51.3 & 46.3 & -4.9 & 5.5 & 5.0 & -0.4 & 16.7 & 17.6 & 0.9 & 26.6 & 31.0 & 4.5 \\
\hline Finland & 41.8 & 55.3 & 13.6 & 37.0 & 25.0 & -12.0 & 1.7 & 2.8 & 1.1 & 19.5 & 16.9 & -2.6 \\
\hline France & 46.1 & 42.5 & -3.7 & 11.5 & 9.1 & -2.4 & 7.4 & 5.5 & -1.9 & 35.0 & 42.9 & 8.0 \\
\hline Germany & 46.5 & 47.5 & 1.0 & 15.1 & 23.1 & 8.0 & 6.0 & 2.4 & -3.6 & 32.4 & 27.1 & -5.4 \\
\hline Greece & 46.4 & 15.8 & -30.6 & 12.7 & 3.1 & -9.6 & 9.6 & 9.3 & -0.3 & 31.3 & 71.9 & 40.5 \\
\hline Hungary & 37.0 & 30.7 & -6.3 & 1.7 & 8.1 & 6.4 & 31.2 & 25.4 & -5.8 & 30.1 & 35.8 & 5.7 \\
\hline Ireland & 73.7 & 48.7 & -25.0 & 5.7 & 7.4 & 1.6 & 6.5 & 10.4 & 3.9 & 14.0 & 33.5 & 19.5 \\
\hline Italy & 46.7 & 23.7 & -23.0 & 4.5 & 4.6 & 0.1 & 14.3 & 13.8 & -0.5 & 34.4 & 57.8 & 23.4 \\
\hline Latvia & 44.2 & 45.7 & 1.5 & 3.2 & 3.0 & -0.2 & 27.8 & 21.4 & -6.4 & 24.8 & 30.0 & 5.2 \\
\hline Lithuania & 29.6 & 31.9 & 2.3 & 1.2 & 2.0 & 0.8 & 38.3 & 36.9 & -1.4 & 30.9 & 29.2 & -1.7 \\
\hline Luxembourg & 62.4 & 62.3 & -0.2 & 17.2 & 20.0 & 2.8 & 2.3 & 3.8 & 1.5 & 18.0 & 14.0 & -4.1 \\
\hline Malta & 53.5 & 61.2 & 7.8 & 5.0 & 13.2 & 8.2 & 12.3 & 10.3 & -2.0 & 29.3 & 15.2 & -14.0 \\
\hline Netherlands & 46.1 & 47.2 & 1.1 & 32.5 & 27.1 & -5.5 & 4.0 & 3.3 & -0.7 & 17.3 & 22.5 & 5.2 \\
\hline Poland & 47.8 & 58.5 & 10.8 & 2.1 & 3.6 & 1.5 & 32.2 & 18.7 & -13.5 & 17.9 & 19.2 & 1.3 \\
\hline Portugal & 38.7 & 17.5 & -21.2 & 1.6 & 4.0 & 2.4 & 15.0 & 6.9 & -8.2 & 44.7 & 71.7 & 27.0 \\
\hline Romania & 31.8 & 18.8 & -12.9 & 7.6 & 1.6 & -6.0 & 43.8 & 44.4 & 0.5 & 16.7 & 35.2 & 18.4 \\
\hline Slovakia & 29.2 & 26.7 & -2.5 & 4.2 & 2.2 & -2.0 & 25.3 & 18.1 & -7.2 & 41.3 & 52.9 & 11.7 \\
\hline Slovenia & 51.1 & 18.3 & -32.7 & 2.9 & 1.5 & -1.4 & 17.6 & 29.9 & 12.3 & 28.4 & 50.2 & 21.8 \\
\hline Spain & 75.0 & 24.5 & -50.5 & 3.9 & 2.7 & -1.2 & 3.9 & 10.0 & 6.1 & 17.3 & 62.9 & 45.6 \\
\hline Sweden & 51.6 & 52.4 & 0.7 & 27.7 & 32.3 & 4.7 & 3.4 & 1.8 & -1.6 & 17.3 & 13.5 & -3.8 \\
\hline UK & 44.5 & 39.9 & -4.6 & 18.9 & 20.8 & 1.9 & 5.1 & 5.3 & 0.3 & 31.5 & 33.9 & 2.4 \\
\hline Mean & 47.5 & 38.6 & -8.9 & 11.1 & 10.3 & -0.8 & 15.8 & 15.1 & -0.8 & 25.6 & 36.0 & 10.4 \\
\hline
\end{tabular}

The italic entries are descriptive statistics only, for which commonly no levels of statistical significance are provided.

Note: Shares may not sum up to 100 due to rounding errors. The seven countries with the strongest increase of the detached are shaded dark-grey.

Source: Eurobarometer. 
Table 3. Attitude types based on trust in the national and the European parliament (in percentage)

\begin{tabular}{|c|c|c|c|c|c|c|c|c|c|c|c|c|}
\hline & \multicolumn{3}{|c|}{ Approving } & \multicolumn{3}{|c|}{ National sovereignist } & \multicolumn{3}{|l|}{ Escapist } & \multicolumn{3}{|l|}{ Detached } \\
\hline & $2006 / 07$ & 2013/14 & Difference & $2006 / 07$ & $2013 / 14$ & Difference & $2006 / 07$ & $2013 / 14$ & Difference & $2006 / 07$ & $2013 / 14$ & Difference \\
\hline Austria & 44.0 & 33.7 & -10.3 & 16.8 & 16.4 & -0.5 & 6.5 & 5.0 & -1.5 & 32.7 & 44.9 & 12.2 \\
\hline Belgium & 49.3 & 38.9 & -10.4 & 7.6 & 9.7 & 2.0 & 17.7 & 9.8 & -7.9 & 25.4 & 41.6 & 16.3 \\
\hline Bulgaria & 16.2 & 14.9 & -1.2 & 1.1 & 1.5 & 0.5 & 54.6 & 48.2 & -6.4 & 28.1 & 35.3 & 7.2 \\
\hline Croatia & 17.0 & 12.3 & -4.7 & 4.6 & 2.5 & -2.1 & 21.6 & 28.3 & 6.7 & 56.8 & 56.8 & 0.1 \\
\hline Cyprus & 46.8 & 9.6 & -37.2 & 11.4 & 9.2 & -2.1 & 19.3 & 9.6 & -9.7 & 22.5 & 71.6 & 49.1 \\
\hline Czech Republic & 19.9 & 10.8 & -9.1 & 1.6 & 2.7 & 1.1 & 45.8 & 24.5 & -21.3 & 32.7 & 61.9 & 29.3 \\
\hline Denmark & 56.0 & 41.8 & -14.2 & 22.9 & 19.0 & -3.9 & 5.6 & 8.5 & 2.8 & 15.5 & 30.7 & 15.3 \\
\hline Estonia & 48.1 & 35.8 & -12.3 & 4.6 & 4.2 & -0.3 & 26.4 & 23.6 & -2.7 & 20.9 & 36.4 & 15.4 \\
\hline Finland & 46.0 & 43.4 & -2.6 & 24.6 & 20.3 & -4.3 & 4.4 & 5.4 & 1.0 & 25.1 & 30.9 & 5.8 \\
\hline France & 32.4 & 17.3 & -15.1 & 7.0 & 7.4 & 0.4 & 18.4 & 16.9 & -1.4 & 42.2 & 58.3 & 16.2 \\
\hline Germany & 35.4 & 28.2 & -7.2 & 8.6 & 20.9 & 12.3 & 13.4 & 4.8 & -8.5 & 42.7 & 46.0 & 3.4 \\
\hline Greece & 45.8 & 8.9 & -36.9 & 8.0 & 4.0 & -4.0 & 18.5 & 12.1 & -6.3 & 27.7 & 75.0 & 47.3 \\
\hline Hungary & 32.2 & 23.9 & -8.4 & 2.0 & 9.8 & 7.8 & 38.3 & 25.0 & -13.3 & 27.5 & 41.4 & 13.9 \\
\hline Ireland & 44.8 & 16.8 & -28.0 & 2.4 & 4.3 & 1.9 & 23.7 & 17.7 & -6.0 & 29.1 & 61.2 & 32.1 \\
\hline Italy & 38.9 & 12.0 & -26.9 & 2.9 & 1.9 & -1.0 & 22.0 & 15.7 & -6.4 & 36.2 & 70.4 & 34.3 \\
\hline Latvia & 19.4 & 14.7 & -4.7 & 3.4 & 4.2 & 0.8 & 37.1 & 31.2 & -6.0 & 40.1 & 50.0 & 9.8 \\
\hline Lithuania & 16.0 & 13.5 & -2.5 & 0.9 & 1.2 & 0.3 & 57.4 & 47.1 & -10.4 & 25.7 & 38.2 & 12.5 \\
\hline Luxembourg & 52.5 & 34.0 & -18.5 & 15.6 & 19.7 & 4.1 & 7.7 & 10.3 & 2.6 & 24.2 & 36.0 & 11.8 \\
\hline Malta & 48.5 & 48.3 & -0.2 & 3.8 & 14.7 & 10.9 & 17.9 & 15.9 & -2.0 & 29.8 & 21.1 & -8.7 \\
\hline Netherlands & 45.9 & 33.2 & -12.8 & 16.6 & 16.8 & 0.2 & 12.1 & 8.7 & -3.4 & 25.3 & 41.3 & 16.0 \\
\hline Poland & 12.9 & 18.3 & 5.4 & 1.6 & 1.3 & -0.3 & 59.4 & 29.9 & -29.5 & 26.1 & 50.5 & 24.4 \\
\hline Portugal & 44.0 & 12.5 & -31.5 & 3.1 & 2.0 & -1.1 & 24.0 & 14.7 & -9.3 & 28.9 & 70.8 & 41.9 \\
\hline Romania & 22.0 & 13.7 & -8.2 & 1.5 & 2.2 & 0.7 & 54.3 & 41.6 & -12.7 & 22.3 & 42.5 & 20.2 \\
\hline Slovakia & 33.7 & 21.7 & -12.0 & 4.9 & 4.1 & -0.8 & 34.8 & 22.5 & -12.3 & 26.6 & 51.7 & 25.1 \\
\hline Slovenia & 36.8 & 4.9 & -31.9 & 2.2 & 1.1 & -1.0 & 33.8 & 32.8 & -1.0 & 27.2 & 61.1 & 33.9 \\
\hline Spain & 49.4 & 6.5 & -42.9 & 2.9 & 1.4 & -1.5 & 16.8 & 12.6 & -4.2 & 30.8 & 79.4 & 48.6 \\
\hline Sweden & 41.8 & 38.7 & -3.1 & 22.7 & 31.7 & 9.0 & 7.8 & 2.8 & -5.0 & 27.7 & 26.8 & -0.9 \\
\hline UK & 25.5 & 14.6 & -11.0 & 13.4 & 11.8 & -1.6 & 10.1 & 6.9 & -3.2 & 50.9 & 66.7 & 15.8 \\
\hline Mean & 36.5 & 22.2 & -14.2 & 7.8 & 8.8 & 1.0 & 25.3 & 19.0 & -6.3 & 30.4 & 50.0 & 19.6 \\
\hline
\end{tabular}

The italic entries are descriptive statistics only, for which commonly no levels of statistical significance are provided.

Note: Shares may not sum up to 100 due to rounding errors. The seven countries with the strongest increase of the detached are shaded dark-grey.

Source: Eurobarometer. 
Looking only at average changes across EU member states (see the bottom line of each table), Table 2 indicates that the share of the 'escapist' and the 'national sovereignist' did not change during the crisis. In the aggregate, these groups exhibit stagnation. The share of the 'approving', in contrast, is reduced from about 48 to $39 \%$, while the 'detached' group grows from 26 to $36 \%$ on average.

A similar picture emerges from Table 3. While the share of the 'national sovereignist' is again stable, however, the 'escapist' group shrinks from about 25 to $19 \%$ on average. In other words, trust in the EU has become less of a substitute for a shortage of trust in national parliaments. More importantly, though, the main result from Table 2 is clearly confirmed. Independent of the operationalization as satisfaction or trust: while the share of the 'approving' shrinks, the share of the 'detached' increases dramatically as the crisis unfolds. Depending on the indicator, between 36 and $50 \%$ of citizens in the EU have on average become disillusioned with both levels of their democratic system.

This aggregate picture masks some considerable country-specific variations, however, both with respect to levels and changes of group shares. While, for example, the share of 'approving' citizens declined by over 50 percentage points ( $\mathrm{pp}$ ) (satisfaction, Table 2) in Spain, it stagnated at a high level of almost two-thirds of Danish citizens and even increased by 13.6 and $10.8 \mathrm{pp}$ in Finland and Poland, respectively. The largest growth in the shares of 'detached' citizens (between +45.6 and +19.5 , again based on satisfaction) occurred, in descending order, in Spain, Greece, Cyprus, Portugal, Italy, Slovenia and Ireland. Strikingly, virtually the same order can be obtained from the trust variables-with the only difference being that Cyprus, Greece, and Spain switch spots. As it turns out, this list comprises almost one by one of those countries (the so-called GIIPS plus Cyprus and Slovenia) that have at various points in time dominated the media coverage on the Euro-crisis. And this, in turn, is mainly because all of them are (or have been) subject to formal or informal Troikaconditionality. Not surprisingly, then, the aggregate numbers on the development of detachment presented above are strongly influenced by these seven countries: excluding them from the calculation of EU averages, detachment increases more moderately from 24.9 to 28.6 (satisfaction) and from 30.9 to $43.3 \%$ (trust), respectively. This divergence is the first indication that Europe drifts apart.

Figure 1 summarizes this process of change and stability across EU countries in a stylized manner. It comprises four graphs to illustrate changes in attitudes towards the democratic political system between 2006/2007 and 2013/2014, both based on satisfaction and on trust. Positive orientations (between 0 and $100 \%$ ) towards the national system appear on the vertical axis of each graph, those towards the EU on the horizontal axis.

Similar to the logic presented in Table 1, we may label those countries in the upper-left quadrant of each graph as 'national sovereignist', those in the bottom-right as 'escapist', those in the upper-right as 'approving' and finally those in the bottom-left quadrant as 'detached'.

We do not engage in a thorough discussion of idiosyncratic country-movements here, but focus only on the aspect that is most relevant to our argument: while the bottom-left quadrant of the 'detached' was entirely (satisfaction), or almost (trust) deserted in 2006/2007, it is now quite densely populated mostly by countries from the Eurozone's periphery. In the past, a majority of citizens in European countries shared positive feelings about their democratic system at least with respect to one of its two crucial levels: be it the national one among the 'national sovereignist', or the European among the 'escapist'. While Figure 1 illustrates this pattern only 

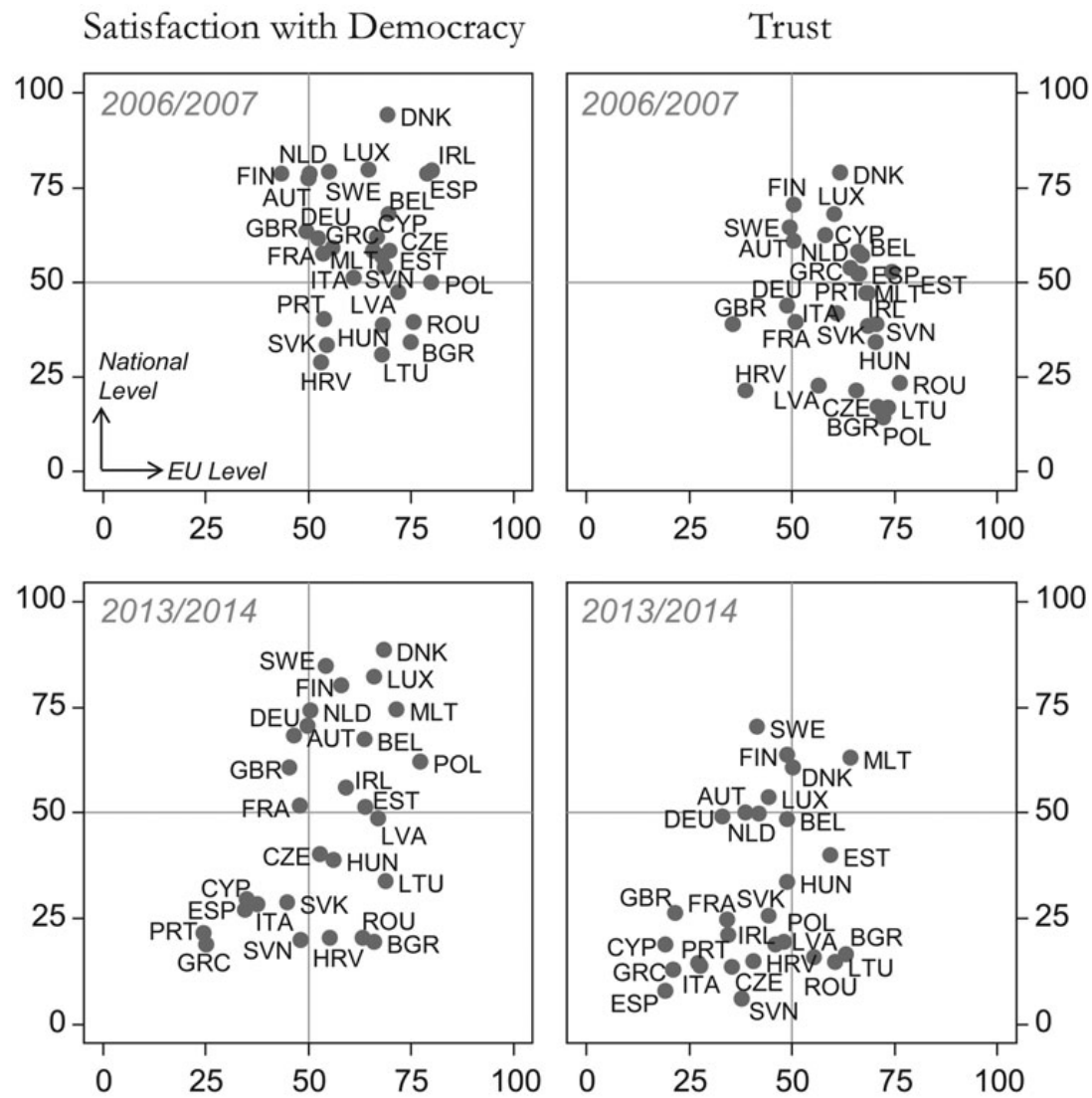

Figure 1. The divide of Europe in terms of support for democracy.

for 2006/2007, the same picture could be obtained for every year between 2000 and 2010 for which we have data. The wide-spread, simultaneous loss of support for democracy at both levels is therefore an entirely new phenomenon in Europe. As it seems mostly confined to the deficit countries of the Eurozone's periphery, this is yet another indication that Europe drifts apart. The remainder of this article explores in how far this can be attributed to the policies of economic adjustment pursued during the crisis.

\section{The dividing potential of the Euro}

In this section, we test our hypothesis that the rising share of detached citizens in deficit countries is a result of externally imposed policies of internal devaluation.

\subsection{Data}

Our dependent variable is the annual (for satisfaction) or semi-annual (for trust) change rate (first difference) in country-specific population shares of the detached. We present three conceptually identical regression models for each version of the dependent variable. 


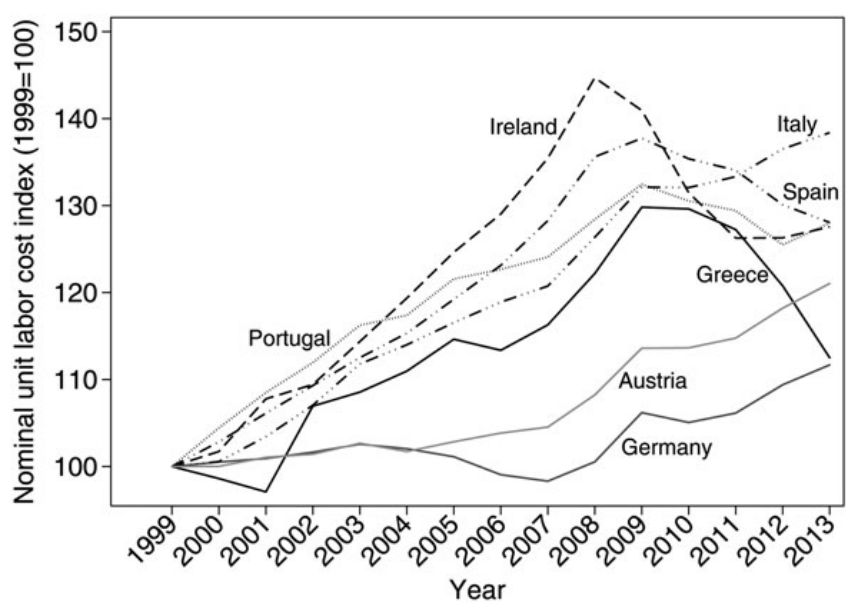

Figure 2. Development of nominal unit labour costs in selected countries (index, 1999=100).

Our main independent variable consists of an interaction term of two factors. The first is the annual change in nominal unit labour costs (ULC) (index in euro, $2005=100$ ). High ULC may indicate low competitiveness, which could in principle be improved through productivity-enhancing measures or through lower wages-or, more specifically, average wage growth below productivity growth. Productivity improvements, however, are more of a long-term approach to bringing down ULC, often employed in combination with union wage restraint, as illustrated by the German strategy of regaining its export competitiveness in the early 2000s (Scharpf, 2013b, p. 116 ff.). That is, they do not tend to trigger those kinds of relatively sharp annual ULC reductions needed to quickly restore competitiveness and correct external imbalances in the face of an immediate crisis. In such situations, the only way out lies in sharp reductions in domestic wages and prices relative to a country's trading partners. This, in turn, can be achieved either through an external or an internal devaluation: No matter which approach is chosen, since our ULC indicator is measured in Euros, both will be reflected in lower nominal ULC. Take the UK as an example, where ULC decreased by about 16 pp in 2007-2009, which is almost completely accounted for by a $22 \%$ depreciation of the freely floating pound sterling over that period. ${ }^{2}$ Since such an external devaluation/depreciation should not affect democratic legitimacy, while an externally imposed internal devaluation should, we do not expect any systematic effect of changes in ULC on detachment.

For countries within the Eurozone, however, any notable year-on-year reduction in ULC should be the result of an internal devaluation. Unsurprisingly, then, this is exactly what we observe when tracing the development of that indicator for selected Eurozone members (see Figure 2): the policies of internal devaluation pursued by deficit countries in the wake of the Great Recession translate into sharply declining ULC from around 2008-2010 onwards. Similarly, the economic division of the Eurozone into competitive (as exemplified by

2 Exchange rates measured as nominal effective exchange rates. Source: Bank for International Settlements. 
Austria and Germany) and less competitive nations, that had developed during the first decade of EMU, is borne out in the data.

Therefore, we combine the ULC indicator with a Eurozone membership dummy and use the resulting interaction term as our main proxy for externally imposed internal devaluation policies within the Eurozone. This operationalization has two advantages. First, it ensures that internal devaluations are captured only if they have been imposed upon countries as a consequence of them being a Eurozone member. The internal devaluation pursued by Latvia, for instance, which has not been part of the Eurozone before 2014, and unilaterally chose not to leave the ERM II and devalue its currency, is not captured. ${ }^{3}$ Second, falling ULC result from a whole range of policy measures implemented under the rubric of 'economic adjustment' in the Eurozone's periphery in order to restore export competitiveness, thereby rebalance trade accounts, regain access to international bond markets and eventually rekindle (more export-led) economic growth. Such policies typically include public sector and welfare cuts, supply-side structural reforms and a broad range of other consolidation measures. Precisely for their immediate recessionary effects, many of these will fuel further reductions in wages and prices, which, as they accumulate, eventually translate into decreasing ULC. In other words, our ULC indicator captures the final outcome of the whole multi-faceted process of internal devaluation through 'economic adjustment' in deficit countries. From a methodological viewpoint, it has a built-in time lag. We therefore do not add another formal lag to the variable in our regression models.

In addition to the ULC*EMU interaction term, these models contain a second interaction term that helps us appreciate the ways in which Eurozone membership may spark political detachment. It is made up of the change in unemployment rates, and, as before, an EMU dummy. ${ }^{4}$ As shown in the 'economic voting' literature (Duch and Stevenson, 2008; also see Kriesi, 2014), attitudes towards the government and the political system in general are negatively affected by a worsening economy. Within the theoretical framework of this article, rising unemployment tends to undermine output legitimacy. We therefore expect it to be positively associated with rising detachment both within and outside EMU-i.e. the main effect of unemployment should be positive on average.

More importantly, however, the adverse effect of unemployment should be much stronger within the Eurozone. This is mainly because EMU membership deprives countries not only of the most potent instrument to tackle their competitiveness problems (i.e. an external devaluation), but also of a whole range of macroeconomic tools to fight the recession from the demand side. Rising detachment may therefore partly stem from a government's inability to combat rising unemployment with its depleted macroeconomic toolkit (Polavieja, 2013). While this logic differs from our main argument about the effect of internal devaluations, a significant coefficient on the unemployment*EMU-interaction term would nonetheless lend additional support to our interpretation that the Euro itself is contributing to the division of Europe.

However, the effects of our two interaction terms cannot easily be delineated from one another. On the one hand, unemployment"EMU captures a somewhat different aspect than

3 For details on Latvia's decision to devalue internally, see e.g. Financial Times from June 5, 2009 ('Latvia bank rejects devaluation call') or the blog post by Olivier Blanchard on voxeu.org (http://www.voxeu. org/article/lessons-latvia) from June 12, 2012, last accessed on October 20, 2015.

4 Our results are unchanged when we use GDP growth instead of changes in unemployment. 
ULC*EMU-i.e. the inability to do something about the crisis rather than the implementation of an unpopular response. On the other hand, insofar as the process of internal devaluation causes unemployment (which it undoubtedly does), it captures part of what we intend to measure with the ULC*EMU-term. In particular, it should account for some portion of the variance in detachment that is explained by the damage to output legitimacy. This is a strong test of our argument that both output and input legitimacy are important for democratic support. A significant effect of the ULC*EMU-interaction term would now be another indication that detachment rises not simply for the adverse economic consequences of internal devaluation (output), but also because citizens had not much say in bringing these policies about (input).

A number of control variables enter our models. The first is the change in long-term interest rates as a proxy for the external pressure exerted by financial markets (see Armingeon and Guthmann, 2014). One could argue that this is captured by our main ULC*EMU-interaction already, since rising bond yields are shown to result from competitiveness imbalances within the Eurozone (De Grauwe, 2012; Johnston et al., 2014). The internal devaluation processes employed to correct those imbalances (often triggered or accompanied by bond market pressure) translate into falling ULC (and eventually rising detachment) only with some time-lag, though. Many governments, in contrast, tend to quickly enter 'panic mode' in response to sharply spiking bond yields, and start announcing one drastic reform programme after another. In consequence, rising interest rates may be associated with growing detachment already. Second, we control for changes of national governments within 12 months before a Eurobarometer interview period. Government changes should be negatively related to detachment, as voters tend to hope that the new executive changes things for the better. Third, we include the levels of three of the four types of orientations in the previous period $(t-1)$, with the 'trusting' as the reference group. Countries show systematic differences with respect to the shares of the 'national sovereignist' and the 'escapist', for example. It should make a difference whether a country starts out with, say, 4 or $45 \%$ of politically detached at the beginning of the crisis. Finally, we add a lagged dependent variable (LDV) to our models. The range of the share of the detached is limited between 0 and $100 \%$. Since these percentage shares cannot grow indefinitely, we expect some convergence processes (i.e. an expected negative sign) in change rates (Beck and Katz, 2011). See Appendix A for an overview of all operationalizations and data sources.

\subsection{Method}

We estimate pooled time-series cross-sectional regression models based on annual and semiannual data. Annual data on democratic satisfaction are from 2002 to 2014; semi-annual data on trust are from spring 2004 to spring 2014. The change rates in the relevant country-specific shares of the detached (three models based on satisfaction, three on trust) are regressed on a vector of independent variables. The models are specified as follows:

$$
\begin{aligned}
\Delta y_{i t}= & \alpha+\beta_{1} \Delta y_{i t-1}+\beta_{2} \Delta \mathrm{ULC}_{i t}+\beta_{3} \mathrm{EMU}_{i t}+\beta_{4} \Delta \mathrm{ULC} * \mathrm{EMU}_{i t}+\beta_{5} \Delta \mathrm{Unemp} \\
& +\beta_{6} \Delta \mathrm{Unemp} * \mathrm{EMU}_{i t}+\sum_{k=1}^{k} \gamma_{k} \text { Controls }_{k i t}+e_{i t},
\end{aligned}
$$

where $\Delta y_{i t}$ is the dependent variable, $\alpha$ the constant, $\beta_{1}$ the estimator for the LDV and $\beta_{2}$ to $\beta_{6}$ are the coefficients for our main and secondary interaction term and their components. 
Finally, $\gamma_{k}$ are estimators for the control variables described above, and $e_{i t}$ is an idiosyncratic error. Based on statistical tests (Hausman and joint $F$-tests indicate significant unit heterogeneity), we include unit and time fixed-effects (not shown), and estimate OLS coefficients with panel-corrected standard errors (PCSEs) to account for heteroscedastic and serially correlated errors.

We also estimated a broad variety of different models to evaluate the robustness of our findings. Among others, we used alternative indicators for internal devaluations (based on real wages, real effective exchange rates or the cyclically adjusted primary balance), we added additional control variables (such as the subjective assessment of the economy, or corruption), employed different estimation techniques (e.g. without country and/or year dummies, without a LDV and/or PCSEs) and excluded the most influential observations from the data (such as the whole series for Greece). In all these robustness tests, our main findings remain substantially unchanged. Finally, we found that our main interaction effect is insignificant in the pre-2008 period, whereas it becomes highly significant after 2008 . This is not surprising given that there have been no substantial externally imposed internal devaluations in our sample before the crisis (see Figure 2).

\subsection{Results}

Table 4 shows the results of our empirical analysis in three regression models each for satisfaction and trust. Models 1 and 4 contain only the ULC*EMU-interaction, Models 2 and 5 only the unemployment*EMU-interaction and in Models 3 and 6 both are included.

Our main result is unambiguous: an externally imposed internal devaluation is associated with a significant increase in detachment. In substantive terms (see Table 5), as ULC decrease by $10 \mathrm{pp}$ in a Eurozone country, the share of the detached rises by about $8 \mathrm{pp}$ (satisfaction, model 3) and 5 pp (trust, Model 6) on average. Recall that the trust-models are based on semiannual data, so the coefficients should be doubled to facilitate a straightforward comparison with those obtained from the democracy models. As expected, falling ULC outside EMU do not affect political detachment in a systematic way. When interpreting the effect of internal devaluation policies in the Eurozone it is important to keep in mind that some part of it (i.e. the recessionary consequences associated with an erosion of output legitimacy) is captured by unemployment and the unemployment*EMU-interaction already.

The effect of unemployment also corresponds to our theoretical expectations: rising unemployment has a much stronger effect inside EMU. As unemployment increases by 5 pp, detachment rises by about 7.5 pp (satisfaction, Model 3) for Eurozone countries, but not significantly outside EMU. This is consistent with our explanation that rising detachment in Eurozone crisis countries may also stem from their governments' impotency to counter rising unemployment with traditional (Keynesian) policies that stimulate aggregate demand (also see Polavieja, 2013).

The effects of the control variables are mostly in the expected direction. Rising interest rates are associated with growing detachment, but the effect is significant only based on the democracy variables. Government changes, as well as the share of the 'escapist' and 'national sovereignist', have no significant effects at all. More important is the share of the detached: where it was high in the previous period already, it is unlikely to increase much further.

In summary, our hypothesis is strongly supported by the data: rising detachment in the Eurozone's periphery can to a considerable degree be attributed to the policies of economic 
Table 4. Regression models-changes in share of the detached

\begin{tabular}{|c|c|c|c|c|c|c|}
\hline & \multicolumn{3}{|c|}{ Satisfaction with democracy } & \multicolumn{3}{|l|}{ Trust } \\
\hline & Model 1 & Model 2 & Model 3 & Model 4 & Model 5 & Model 6 \\
\hline$\Delta$ Detached $_{t-1}(\mathrm{LDV})$ & $\begin{array}{l}-0.23 * \\
(1.83)\end{array}$ & $\begin{array}{l}-0.28^{* *} \\
(2.03)\end{array}$ & $\begin{array}{c}-0.24^{*} \\
(1.91)\end{array}$ & $\begin{array}{l}-0.23^{* * *} \\
(2.96)\end{array}$ & $\begin{array}{l}-0.24 * * * \\
(3.11)\end{array}$ & $\begin{array}{l}-0.23^{* * *} \\
(3.02)\end{array}$ \\
\hline Detached $_{t-1}($ level $)$ & $\begin{array}{l}-0.26^{* * * *} \\
(3.62)\end{array}$ & $\begin{array}{l}-0.15^{* *} \\
(1.97)\end{array}$ & $\begin{array}{l}-0.24^{* * * *} \\
(3.19)\end{array}$ & $\begin{array}{l}-0.20^{* * * *} \\
(3.33)\end{array}$ & $\begin{array}{l}-0.15^{* * *} \\
(2.50)\end{array}$ & $\begin{array}{l}-0.20^{* * * *} \\
(3.41)\end{array}$ \\
\hline Escapist $_{t-1}$ (level) & $\begin{array}{c}0.10 \\
(1.16)\end{array}$ & $\begin{array}{c}-0.01 \\
(0.19)\end{array}$ & $\begin{array}{c}0.04 \\
(0.44)\end{array}$ & $\begin{array}{l}-0.03 \\
(0.48)\end{array}$ & $\begin{array}{l}-0.01 \\
(0.20)\end{array}$ & $\begin{array}{c}-0.04 \\
(0.60)\end{array}$ \\
\hline $\begin{array}{l}\text { National sovereignist } t_{t-1} \\
\quad \text { (level) }\end{array}$ & $\begin{array}{c}0.11 \\
(1.27)\end{array}$ & $\begin{array}{c}0.14 \\
(1.50)\end{array}$ & $\begin{array}{c}0.14 \\
(1.55)\end{array}$ & $\begin{array}{c}0.06 \\
(0.61)\end{array}$ & $\begin{array}{l}0.08 \\
(0.72)\end{array}$ & $\begin{array}{c}0.07 \\
(0.65)\end{array}$ \\
\hline EMU member (dummy) & $\begin{array}{l}1.00 \\
(0.62)\end{array}$ & $\begin{array}{c}-0.22 \\
(0.09)\end{array}$ & $\begin{array}{c}1.34 \\
(0.64)\end{array}$ & $\begin{array}{c}2.23 \\
(1.28)\end{array}$ & $\begin{array}{c}1.42 \\
(0.91)\end{array}$ & $\begin{array}{c}2.33 \\
(1.39)\end{array}$ \\
\hline$\Delta$ Unit labour costs & $\begin{array}{c}0.01 \\
(0.19)\end{array}$ & $\begin{array}{l}-0.18^{* * *} \\
(2.43)\end{array}$ & $\begin{array}{l}-0.03 \\
(0.57)\end{array}$ & $\begin{array}{c}0.03 \\
(0.46)\end{array}$ & $\begin{array}{c}-0.05 \\
(0.77)\end{array}$ & $\begin{array}{c}0.03 \\
(0.41)\end{array}$ \\
\hline$\Delta$ Unit labour costs * EMU & $\begin{array}{l}-0.90^{* * *} \\
(5.02)\end{array}$ & & $\begin{array}{l}-0.75^{* * *} \\
(3.63)\end{array}$ & $\begin{array}{l}-0.44^{* * *} \\
(3.11)\end{array}$ & & $\begin{array}{l}-0.51^{* * *} \\
(3.40)\end{array}$ \\
\hline$\Delta$ Unemployment & $\begin{array}{l}0.76 * * * \\
(3.44)\end{array}$ & $\begin{array}{c}0.29 \\
(1.04)\end{array}$ & $\begin{array}{c}0.27 \\
(1.34)\end{array}$ & $\begin{array}{l}0.14^{* * *} \\
(2.68)\end{array}$ & $\begin{array}{c}0.08 \\
(1.41)\end{array}$ & $\begin{array}{c}0.06 \\
(0.99)\end{array}$ \\
\hline$\Delta$ Unemployment $*$ EMU & & $\begin{array}{l}1.61^{* * * *} \\
(2.61)\end{array}$ & $\begin{array}{l}1.24^{* * *} \\
(2.58)\end{array}$ & & $\begin{array}{c}0.18^{*} \\
(1.69)\end{array}$ & $\begin{array}{l}0.24^{* * *} \\
(2.30)\end{array}$ \\
\hline$\Delta$ Interest rate & $\begin{array}{l}0.61^{* *} \\
(2.15)\end{array}$ & $\begin{array}{l}0.68^{* *} \\
(2.24)\end{array}$ & $\begin{array}{l}0.54 * * \\
(1.98)\end{array}$ & $\begin{array}{r}-0.00 \\
(0.01)\end{array}$ & $\begin{array}{c}0.10 \\
(0.37)\end{array}$ & $\begin{array}{c}0.01 \\
(0.05)\end{array}$ \\
\hline Government changes & $\begin{array}{c}-0.37 \\
(0.75)\end{array}$ & $\begin{array}{r}-0.50 \\
(0.98)\end{array}$ & $\begin{array}{l}-0.48 \\
(0.94)\end{array}$ & $\begin{array}{c}0.20 \\
(0.77)\end{array}$ & $\begin{array}{c}0.26 \\
(1.03)\end{array}$ & $\begin{array}{c}0.19 \\
(0.76)\end{array}$ \\
\hline$R^{2}$ & 0.48 & 0.47 & 0.50 & 0.45 & 0.45 & 0.46 \\
\hline$N$ & 269 & 269 & 269 & 527 & 527 & 527 \\
\hline
\end{tabular}

Note: Country and year fixed-effects included. $z$ statistic in parentheses.

$* P<0.1 ; * * P<0.05 ; * * P<0.01$.

Table 5. Marginal effects of ULC and unemployment changes on changes in detachment

\begin{tabular}{llllll}
\hline & \multicolumn{2}{l}{$\begin{array}{l}\text { Marginal effect of } \Delta \text { Unit } \\
\text { labour costs }\end{array}$} & & \multicolumn{2}{l}{$\begin{array}{l}\text { Marginal effect of } \Delta \\
\text { Unemployment }\end{array}$} \\
\cline { 2 - 3 } \cline { 5 - 6 } & Democracy & Trust & & Democracy & Trust \\
\hline EMU country & $-0.78^{* * *}$ & $-0.48^{* * *}$ & & $1.51^{* * *}$ & $0.29^{* * *}$ \\
Non-EMU country & $(0.19)$ & $(0.15)$ & & $(0.44)$ & $(0.09)$ \\
Difference & -0.03 & 0.03 & & 0.27 & 0.06 \\
& $(0.06)$ & $(0.07)$ & & $(0.20)$ & $(0.06)$ \\
& $-0.75^{* * *}$ & $-0.51^{* * *}$ & & $1.24^{* * *}$ & $0.24^{* *}$ \\
& $(0.21)$ & $(0.15)$ & & $(0.48)$ & $(0.10)$ \\
\hline
\end{tabular}

Note: Based on Model 3 (democracy) and Model 6 (trust). Standard errors in parentheses.

*P< $0.1 ; * P<0.05 ; * * P<0.01$. 
adjustment. The 'democratic division' of Europe illustrated in Figure 1 is an unintended consequence of EMU itself.

\section{Actual and counterfactual trends in detachment in four typical cases}

According to our main argument, political detachment rises strongly when two conditions are fulfilled: First, countries are pursuing internal devaluation policies, which, for their adverse socio-economic consequences, lack output legitimacy. Second, these policies are externally imposed upon countries by the economic imperatives of the non-optimal EMU, which deprives them of any other instruments to correct the competitiveness imbalances they had accumulated over the past decade. Internal devaluation therefore also lacks input legitimacy.

Both conditions-we call them 'treatments' from now on-are thus necessary, but only in combination are they sufficient for detachment to rise strongly. This suggests four typical cases that may help us clarify the causal mechanism relating the two treatments to rising detachment: Latvia and Sweden as non-EMU countries (Latvia joined only in 2014), and Germany and Greece as EMU members. Two of these countries did engineer an internal devaluation (Greece involuntarily inside EMU, and Latvia voluntarily outside), the other two did not.

In this section, we compare the development of political detachment in these four cases to their respective counterfactuals, which are created based on the assumption that they had not received the respective treatment of interest. For each of the four cases either EMU membership or 'internal devaluation' (ID from now on) serves as treatment, while the other is held constant. Moreover, we also compare the typical case of Greece to its counterfactual which had either not been in the Eurozone or had not experienced an ID-this comparison most closely resembles what we estimate with the ULC"EMU interaction term in the regression analysis.

Using the synthetic control method described by Abadie et al. (2015), our counterfactual cases ('synthetic controls') are composed of weighted averages of countries (combinations of 'comparison units') that best resemble each of our four cases during the period before 'the intervention'. The 'intervention' is, in our context, the moment when ID policies were triggered-for the most part, the year 2010 seems appropriate, but our results are unchanged if we use 2009 as the intervention year.

Figure 3 shows the development of detachment between 2004 and 2014 in our four typical cases and their counterfactuals by making six different comparisons (graphs 1-6). We only show results based on the satisfaction variables. Calculations based on trust yield no substantively different results, however. Synthetic Greece (graph 1) is composed of other Eurozone members that did not experience an ID (we define a country as having experienced an ID when ULC fell on average between 2010 and 2013, but the same patterns are obtained based on 2009-2013). The mirror image is synthetic Germany (graph 2), which is composed of other Eurozone members that did experience an ID. In other words, both across Greece and synthetic Greece, and across Germany and synthetic Germany, EMU membership is held constant, and ID is the treatment. Synthetic Latvia (graph 3) is composed of other non-EMU members that did not engineer an ID. That is, ID is the treatment again, but now non-EMU membership is held constant (as opposed to graphs 1 and 3 where EMU membership was held constant). In graph 4, Latvia is compared do another version of synthetic Latvia, which is composed of Eurozone members that did also experience an ID (i.e. now 
(1) Greece (EMU, ID) vs. synthetic Greece (EMU, no ID)

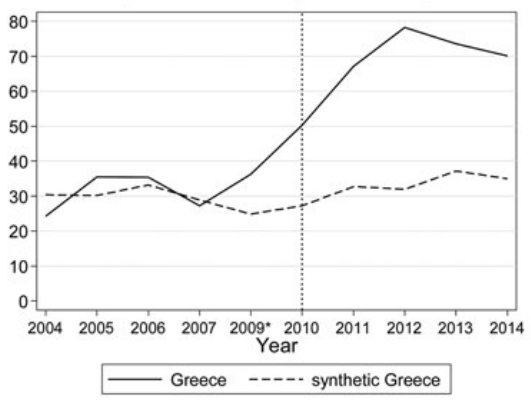

(3) Latvia (non-EMU, ID) vs. synthetic Latvia (non-EMU, no ID)

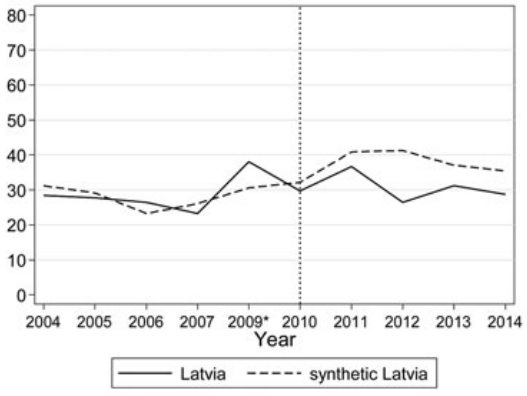

(5) Sweden (no ID, non-EMU) vs. synthetic Sweden (no ID, EMU)

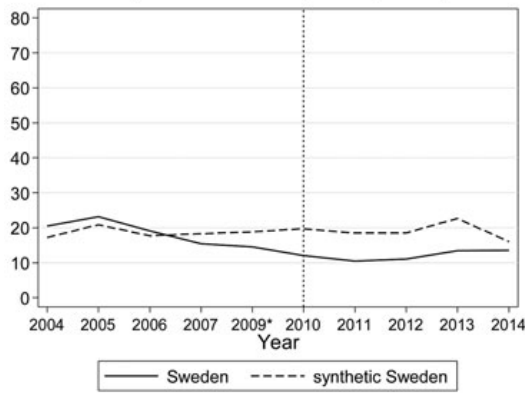

(2) Germany (EMU, no ID) vs. synthetic Germany (EMU, ID)

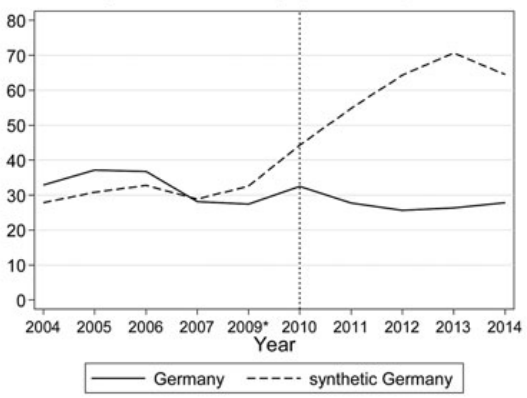

(4) Latvia (ID, non-EMU) vs. synthetic Latvia (ID, EMU)

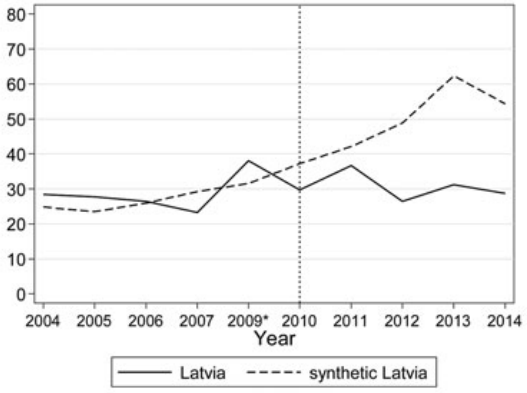

(6) Greece (EMU, ID) vs. synthetic Greece (EMU, no ID or non-EMU)

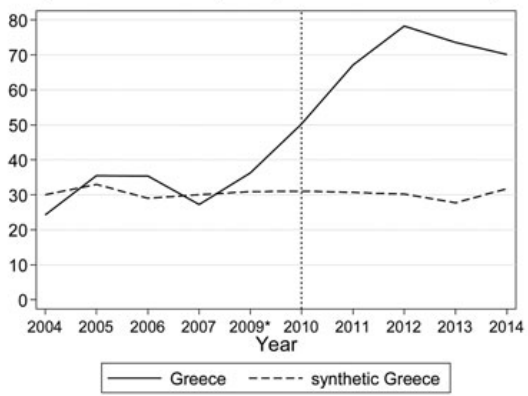

Note: Data on satisfaction is missing for 2008. We use 2010 as the intervention year (i.e. the initiation of ID), but our results are unchanged when we use 2009 instead. Composition of synthetic controls: (1) Synthetic Greece: 0.34 Luxembourg, 0.34 France, 0.30 Slovakia, 0.01 Italy. (2) Synthetic Germany: 0.36 Greece, 0.27 Cyprus, 0.25 Portugal, 0.12 Spain. (3) Synthetic Latvia: 0.71 Czech Republic, 0.29 Poland. (4) Synthetic Latvia: 0.56 Cyprus, 0.32 Slovenia, 0.12 Portugal. (5) Synthetic Sweden: 0.55 Netherlands, 0.25 Finland, 0.21 Luxembourg. (6) Synthetic Greece: 0.49 Hungary, 0.39 Germany, 0.12 Luxembourg.

Figure 3. Comparison of typical cases using the synthetic control method.

EMU-membership is the treatment, and presence of an ID is held constant). We make two comparisons based on Latvia, because we have too few cases in our sample (which, like Latvia, implemented an ID outside EMU) to reasonably combine them into a counterfactual 
for other countries. Next, synthetic Sweden (graph 5) is composed of countries which, like Sweden, did not experience an ID, but are part of EMU (as for the comparison in graph 4, EMU is the treatment, but now absence of ID is held constant). Finally, the interaction effect of the regression analysis is illustrated with another synthetic Greece (graph 6) composed of countries that did not experience an ID inside EMU.

In graph 1 we see that, from around 2009/2010 onwards, the distance between Greece and its counterfactual widens dramatically: Detachment rises to almost $80 \%$ in Greece, but stagnates at about $30 \%$ in its synthetic opposite, which suggests what would have happened in Greece had it not experienced an ID. The mirror image is given by Germany (graph 2): Had Germany been forced to implement an ID, detachment could have been expected to rise considerably_synthetic Germany looks almost like actual Greece does in terms of political detachment. In graph 3, no substantial differences are discernible between Latvia and its counterfactual that did non-engineer an ID. In other words, ID per se does not seem to trigger rising detachment, as long as it is not externally imposed upon a country by the politico-economic imperatives associated with EMU membership. Rather, taken together, graphs 1-3 confirm our expectation that for an ID to trigger rising detachment, Eurozone membership is a necessary condition. With Latvia having largely voluntarily opted for internal (and against external) devaluation, input legitimacy has been maintained and may have substituted somewhat for the inevitable damage done to output legitimacy.

In graphs 4 and 5, we examine the effect of EMU membership given there was an ID programme (Latvia vs. synthetic Latvia), and given there was no such programme (Sweden vs. synthetic Sweden), respectively. Unsurprisingly, in synthetic Latvia (graph 4), detachment rises strongly from about 2010 onwards to peak at around 60\% in 2013, while it keeps fluctuating between 25 and below $40 \%$ in 'actual' Latvia. ${ }^{5}$ There is no substantial difference between Sweden and its synthetic EMU-counterpart. This shows that rising detachment is not merely a Eurozone phenomenon. If, however, EMU membership implies ID policies, as it does for deficit countries, detachment increases considerably.

The final comparison in graph 6 (again between Greece and a synthetic version of it) summarizes the findings from the other graphs: only in combination are EMU membership and ID policies (since this implies a simultaneous erosion of both output and input legitimacy) a sufficient explanation for rising detachment in the Eurozone's periphery. The only difference to graph 1 is the line representing synthetic Greece, which is now (in graph 6) composed of a different set of countries.

\section{Conclusion}

Being deprived of traditional policy instruments to deal with recessions and macroeconomic imbalances, the European debt crisis left many Eurozone deficit countries with no other options but to implement a policy package of internal devaluation, austerity and structural reforms. What are the consequences of these economic adjustment programmes for the attitudes of citizens towards their democratic political system both at the European and national

5 One could argue that Latvians have a greater 'pain tolerance' than West Europeans. This might be a plausible explanation for this case. A systematic analysis would require that we have comparable data on pain tolerance for all countries, however-which we unfortunately do not have. 
level? This was our guiding question. We have argued that, for their lack of democratic legitimacy with respect to both the output- and the input-oriented dimension, externally imposed economic adjustments translated into a broad-based erosion of support for democracy in the affected countries. Obviously, democracy became stalled.

In support of this argument, our empirical analysis has shown that the stronger the internal devaluation imposed upon a country, the larger the increase in the share of detached citizensthose who evaluate both their national and the European political system in a negative light.

Highly heterogeneous national economies have been bound together under the umbrella of the Eurozone. Once an external shock swept over the Atlantic, the zone's most vulnerable countries, burdened by massive macroeconomic imbalances, were forced to implement stringent economic adjustment programmes that were not based on autonomous decisions of the respective peoples. In turn, learning that national democratic politics did not matter any longer, their citizens started to question the legitimacy of the democratic political systems at both the national and EU level. In countries that did not have to adjust, in contrast, such as EMU's surplus or non-EMU countries, citizens had little reason to withdraw their support for the democratic political system. In that sense, the Euro divided the union.

Mair (2013) once pointed to the tension between 'responsible' and 'responsive' governments in economically closely connected nation states-a tension between what governments are obliged to do and what citizens might like them to (Mair, 2013, p. 164). Our analysis complements this sceptic view regarding the viability of democracy in the Eurozone. Once governments behave responsibly and implement the requests by international institutions and markets, they have to relinquish their responsiveness to the preferences of their citizens.

As put differently by Streeck (2014, pp. 79-90), governments have to balance the conflicting demands of two constituencies: their general citizenry on the one hand, and international financial markets on the other. In order to survive the 'economic storm', they have to please the markets with no regard to the legitimate, but often diametrically opposed, demands of the people. The new regime-which some researchers called a 'bureaucratic Caesarism' or 'authoritarian neo-liberalism' (Bruff, 2014; Keucheyan and Durand, 2015)—effectively excluded citizens and social groups from political influence, leading to a loss of support for democracy. This also concurs with an argument by Eichengreen (2008, p. 3) that fixed exchange rate regimes (and for its non-OCA characteristics, we think of EMU as being not much more than a mere system of fixed exchange rates) in an era of capital mobility tend to be incompatible with democratic policymaking.

We argue that this tension is unlikely to be just a temporary phenomenon. Rather, insofar as the Eurozone crisis was caused by economic and institutional diversity, and since the monetary union will not in all likelihood resemble an OCA in the near future, its inherent tension with democratic policymaking will persist. Since a return to the European monetary system as it existed before the Euro is hardly feasible; and since unilaterally quitting the Eurozone would for individual countries also be associated with considerable costs and uncertainty, at the time of writing the most likely perspective is that of muddling through. This is not good for the economy, but it is even worse for democracy.

\section{Acknowledgement}

We thank the three anonymous reviewers for useful comments. 


\section{Funding}

This work was supported by the Swiss National Science Foundation (project numbers 146033 and 143504). A first analysis dealing with this subject was published in German in the Politische Vierteljahresschrift (2015, vol. 36, pp. 506-531).

\section{References}

Abadie, A., Diamond, A. and Hainmueller, J. (2015) 'Comparative Politics and the Synthetic Control Method', American Journal of Political Science, 59, 495-510.

Armingeon, K. and Baccaro, L. (2012) 'The Sorrows of Young Euro: Policy Responses to the Sovereign Debt Crisis'. In Bermeo, N. and Pontusson, J. (eds) Coping with Crisis: Government Reactions to the Great Recession, New York, Russel Sage, pp. 162-197.

Armingeon, K. and Guthmann, K. (2014) 'Democracy in Crisis? The Declining Support for National Democracy in European Countries 2007-2011', European Journal of Political Research, 53, 423-442.

Armingeon, K., Isler, C., Knöpfel, L. and Weisstanner, D. (2015) Supplement to the Comparative Political Data Set - Government Composition 1960-2013, Bern, Institute of Political Science, University of Bern.

Beck, N. and Katz, J. (2011) 'Modeling Dynamics in Time-Series-Cross-Section Political Economy Data', Annual Review of Political Science, 14, 331-352.

Becker, J. and Jäger, J. (2012) 'Integration in Crisis: A Regulationist Perspective on the Interaction of European Varieties of Capitalism', Competition \& Change, 16, 169-187.

Boyer, R. (2013) 'The Euro Crisis: Undetected by Conventional Economics, Favoured by Nationally Focused Polity', Cambridge Journal of Economics, 37, 533-569.

Bruff, I. (2014) 'The Rise of Authoritarian Neoliberalism', Rethinking Marxism: A Journal of Economics, Culture \& Society, 23, 113-129.

De Grauwe, P. (2012) 'The Governance of a Fragile Eurozone', Australian Economic Review, 45, 255-268.

De Grauwe, P. (2013) 'The Political Economy of the Euro', Annual Review of Political Science, 16, 153-170.

Duch, R. M. and Stevenson, R. T. (2008) The Economic Vote. How Political and Economic Institutions Condition Election Results, Cambridge, Cambridge University Press.

Durand, C. and Keucheyan, R. (2015) 'Financial Hegemocy and the Unachieved European State', Competition \& Change, 19, 129-144.

Eichengreen, B. (2008) Globalizing Capital. A History of the International Monetary System, Princeton and Oxford, Princeton University Press.

Fleming, J. M. (1971) ‘On Exchange Rate Unification’, Economic Journal, 81, 467-488.

Hall, P. A. (2012) 'The Economics and Politics of the Euro Crisis', German Politics, 21, 355-371.

Haller, M. (1999) 'Voiceless Submission or Deliberate Choice? European Integration and the Relation between National and European Identity'. In Kriesi, H., Armingeon, K., Siegrist, H. and Wimmer, A. (eds) Nation and National Identity. The European Experience in Perspective, Chur, Rüegger, pp. 263-296.

Hancké, B. (2013) Unions, Central Banks, and EMU: Labor Market Institutions and Monetary Integration in Europe, Oxford, Oxford University Press.

Hein, E. (2013) 'The Crisis of Finance-Dominated Capitalism in the Euro Area: Deficiencies in the Economic Policy Architecture and Deflationary Stagnation Policies', Journal of Post Keynesian Economics, 36, 325-354.

Hobolt, S. B. and Leblond, P. (2014) 'Economic Insecurity and Public Support for the Euro'. In Bermeo, N. and Bartels, L. M. (eds) Mass Politics in Tough Times, Oxford, Oxford University Press, pp. 128-147. 
Hope, K. (2010, April 30) 'Papandreou braced for fresh fury', Financial Times, London.

Höpner, M. and Lutter, M. (2014) One Currency and Many Modes of Wage Formation: Why the Eurozone is too Heterogeneous for the Euro, MPIfG Discussion Paper 14/14, Cologne, Max Planck Institute for the Study of Societies.

Johnston, A., Hancké, B. and Pant, S. (2014) 'Comparative Advantage in the European Sovereign Debt Crisis', Comparative Political Studies, 47, 1771-1800.

Keucheyan, R. and Durand, C. (2015) 'A Gramscian Outlook on the Crisis of Europe', Historical Materialism, 23, 23-51.

Kriesi, H. (2014) 'The Political Consequences of the Economic Crisis in Europe'. In Bermeo, N. and Bartels, L. M. (eds) Mass Politics in Tough Times. Opinions, Votes, and Protest in the Great Recession, New York, Oxford University Press, pp. 297-333.

Kriesi, H. and Grande, E. (2015) 'The Europeanization of the National Political Debate'. In Cramme, O. and Hobolt, S. B. (eds) Democratic Politics in a European Union Under Stress, Oxford, Oxford University Press, pp. 67-86.

Leibniz-Institut für Wirtschaftsforschung Halle (IWH). (2015) 'Germany's Benefit from the Greek Crisis', IWH Online 7/2015, Halle (Saale), accessed at http://www.iwh-halle.de/d/publik/ iwhonline/io_2015-07.pdf on August 17, 2015.

Mair, P. (2013) 'Smaghi versus the Parties: Representative Government and Institutional Constraints'. In Schäfer, A. and Streeck, W. (eds) Politics in the Age of Austerity, Cambridge, Polity Press, pp. 143-168.

Martinotti, G. and Stefanizzi, S. (1995) 'Europeans and the Nation State'. In Niedermayer, O. and Sinnott, R. (eds) Public Opinion and Internationalized Governance, Vol. 2, New York, Oxford University Press, pp. 163-189.

Mundell, R. A. (1961) 'A Theory of Optimum Currency Areas', The American Economic Review, $51,657-665$.

O’Malley, E. (2011) 'Ireland', European Journal of Political Research. Political Data Yearbook, 50, 1004-1010.

Polavieja, J. (2013) 'Economic Crisis, Political Legitimacy, and Social Cohesion'. In Gallie, D. (ed.) Economic Crisis, Quality of Work, \& Social Integration: The European Experience, Oxford, Oxford University Press, pp. 256-278.

Sacchi, S. (2015) 'Conditionality by Other Means: EU Involvement in Italy's Structural Reforms in the Sovereign Debt Crisis', Comparative European Politics, 13, 77-92.

Scharpf, F. W. (1986, December 12) 'Ein Sprengsatz für die Gemeinschaft. Plädoyer gegen eine Europäische Wirtschafts- und Währungsunion', Die Zeit, Hamburg, 51, 32.

Scharpf, F. W. (2013a) 'Legitimacy Intermediation in the Multilevel European Polity and Its Collapse in the Euro Crisis'. In Armingeon, K. (ed.) Staatstätigkeiten, Parteien und Demokratie. Festschrift für Manfred G. Schmidt, Wiesbaden, Springer VS, pp. 567-597.

Scharpf, F. W. (2013b) 'Monetary Union, Fiscal Crisis and the Disabling of Democratic Accountability'. In Schäfer, A. and Streeck, W. (eds) Politics in the Age of Austerity, Cambridge, Polity Press, pp. 108-142.

Scharpf, F. W. (2013c) Political Legitimacy in a Non-Optimal Currency Area, MPIfG Discussion Paper 13/15, Cologne, Max Planck Institute for the Study of Societies.

Stockhammer, E. (2011) 'Peripheral Europe's Debt and German Wages: The Role of Wage Policy in the Euro Area', International Journal of Public Policy, 7, 83-96.

Stockhammer, E. and Sotiropoulos, D. P. (2014) 'Rebalancing the Euro Area: The Costs of Internal Devaluation', Review of Political Economy, 26, 210-233.

Streeck, W. (2014) Buying Time. The Delayed Crisis of Democratic Capitalism, London and New York, Verso.

Streeck, W. (2015) 'Warum der Euro Europa spaltet statt es zu einigen', Distinguished Lecture in the Social Sciences, Wissenschaftszentrum Berlin, Berlin, accessed at http://wolfgangstreeck.com/ 2015/ on April 21, 2015. 
Streeck, W. and Elsässer, L. (2014) Monetary Disunion: The Domestic Politics of Euroland, MPIfG Discussion Paper 14/17, Cologne, Max Planck Institute for the Study of Societies.

Wise, P. (2011, January 14) 'Portuguese begin to see bail-out as inevitable', Financial Times, London.

\section{Appendix A: operationalization and data sources}

Data coverage: 2002-2014 (EU-15); 2006-2014 (accession countries 2004/2007/2013).

\section{A.1. Dependent variables}

(1) Changes in the share of the 'detached', satisfaction with democracy.

Annual change rates (differences) of the population share reporting dissatisfaction with democracy both on the national and on the European level (aggregated data using post-stratification weights). National level: 'On the whole, are you very satisfied, fairly satisfied, not very satisfied or not at all satisfied with the way democracy works in (YOUR COUNTRY)?' Coded 1 = 'very/fairly satisfied'; $0=$ 'not very/not at all satisfied'; missing = 'don't know'.

European level: 'And how about the way democracy works in the EU?' Coded 1 = 'very/fairly satisfied'; 0 = 'not very/not at all satisfied'; missing = 'don't know'.

Missing: 2008 (all countries); Croatia 2011-2014.

Sources: Eurobarometer waves EB 54.1, 56.2, 58.1, 60.1, 62.0, 63.4, 65.2, 68.1, 72.4, 73.4, 76.3, 78.1, 80.1 and 81.4 (usually fall EB data, except spring in 2005, 2006, 2010 and 2014).

(2) Changes in the share of the 'detached', trust

Half-yearly change rates (differences) of the population share reporting to trust neither the national parliament nor the European Union (aggregated data using post-stratification weights).

National level: 'I would like to ask you a question about how much trust you have in certain institutions. For each of the following institutions, please tell me if you tend to trust it or tend not to trust it. ... - The (NATIONALITY) Parliament'. Coded 1 = 'Tend to trust'; 0 = 'Tend not to trust'; missing = 'don't know'.

European level: 'I would like to ask you a question about how much trust you have in certain institutions. For each of the following institutions, please tell me if you tend to trust it or tend not to trust it. . . . The European Union'. Coded 1 = 'Tend to trust'; 0 = 'Tend not to trust'; missing = 'don't know'.

Missing: none.

Sources: Eurobarometer waves EB 59.1, 60.1, 61, 62.0, 63.4, 64.2, 65.2, 66.1, 67.2, 68.1, 69.2, $70.1,71.3,72.4,73.4,74.2,75.3,76.3,77.3,78.1,79.3,80.1$ and 81.4 (both spring and fall EB data, starting in spring 2003 and ending in spring 2014).

\section{A.2. Independent variables}

(1) Share of the 'detached', 'escapist' and 'national sovereignist'

Population shares reporting political support neither on the national nor the European level (detached), only on the European level (escapists), and only on the national level (national sovereignist), respectively. Calculation: see dependent variable.

(2) Changes of nominal unit labour costs

Annual change rates (percentage changes) of nominal unit labour costs for the whole economy (ratio of labour costs to labour productivity). 
Sources: European Commission, AMECO Online (satisfaction with democracy: annual data, reference year 2005 in 2005 exchange rates); Eurostat (trust: quarterly data, average changes to same period in previous year for two quarters, reference year 2010 in 2010 exchange rate).

\section{(3) Indicator of EMU membership}

Dummy variable coded 1 if the country was a member of the Economic and Monetary Union (EMU) in the given year of the EB wave, and 0 otherwise.

Sources: European Commission.

\section{(4) Changes of unemployment}

Annual change rates (percentage changes) of unemployment rates.

Source: Eurostat (satisfaction with democracy: annual data; trust: quarterly data, average changes to same period in previous year for two quarters).

\section{(5) Changes of long-term interest rates}

Annual changes (differences) of interest rate on long-term (in most cases 10 years) government bonds.

Missing: Estonia (all years), Bulgaria 2002, Croatia 2002-2005, Romania 2002-2005.

Source: Eurostat (satisfaction with democracy: annual data; trust: quarterly data, average changes to same period in previous year for two quarters).

(6) Government changes

Ordinal variable with four values. 2 = election within 12 months of $\mathrm{EB}$ wave and a change in government composition of at least 20 percentage points (based on the parliamentary seat share of governing parties). $1=$ election and a change of less than $20 \% .0=$ no election and no change of government composition larger than $20 \%,-1=$ no election, but a government composition change of at least $20 \%$.

Source: Own calculations based on Armingeon et al. (2015).

\section{Appendix B}

Table B1. Summary statistics

\begin{tabular}{|c|c|c|c|c|c|}
\hline Variable & $N$ & Mean & SD & Minimum & Maximum \\
\hline$\Delta$ Detached (satisfaction with democracy) & 269 & 0.65 & 6.45 & -19.16 & 16.86 \\
\hline$\Delta$ Detached (trust) & 527 & 0.71 & 6.42 & -24.26 & 26.94 \\
\hline Detached $_{t-1}$ & 269 & 29.60 & 13.14 & 3.45 & 78.75 \\
\hline Escapist $_{t-1}$ & 269 & 13.54 & 12.83 & 0.73 & 55.19 \\
\hline National sovereignist $_{t-1}$ & 269 & 11.92 & 10.39 & 0.56 & 38.70 \\
\hline EMU member state & 269 & 0.63 & 0.48 & 0 & 1 \\
\hline$\Delta$ Unit Labour Costs & 269 & 1.93 & 3.90 & -10.46 & 26.85 \\
\hline$\Delta$ Unemployment & 269 & 0.06 & 1.58 & -5.90 & 6.60 \\
\hline$\Delta$ Interest rate & 269 & -0.21 & 1.48 & -12.45 & 6.75 \\
\hline Government changes & 269 & 0.35 & 0.80 & -1 & 2 \\
\hline
\end{tabular}




\section{Appendix C}

Table C1. Correlation matrix (all variables, satisfaction with democracy)

\begin{tabular}{|c|c|c|c|c|c|c|c|c|c|}
\hline & $\begin{array}{l}\Delta \\
\text { Detached }\end{array}$ & Detached $_{t-1}$ & Escapist $_{t-1}$ & $\begin{array}{l}\text { National } \\
\text { sovereignist }_{t-1}\end{array}$ & $\begin{array}{l}\text { EMU } \\
\text { member }\end{array}$ & $\begin{array}{l}\Delta \text { Unit labour } \\
\text { costs }\end{array}$ & $\begin{array}{l}\Delta \\
\text { Unemployment }\end{array}$ & $\begin{array}{l}\Delta \text { Interest } \\
\text { rate }\end{array}$ & $\begin{array}{l}\text { Government } \\
\text { changes }\end{array}$ \\
\hline$\Delta$ Detached & 1.00 & & & & & & & & \\
\hline Detached $_{t-1}$ & -0.11 & 1 & & & & & & & \\
\hline Escapist $_{t-1}$ & 0.06 & $0.23 *$ & 1 & & & & & & \\
\hline $\begin{array}{l}\text { National } \\
\quad \text { sovereignist }_{t-1}\end{array}$ & -0.07 & $-0.51 *$ & $-0.66 *$ & 1 & & & & & \\
\hline EMU member state & 0.03 & $0.20 *$ & $-0.49 *$ & 0.05 & 1 & & & & \\
\hline$\Delta$ Unit labour costs & -0.05 & $-0.26^{*}$ & $0.12 *$ & -0.02 & $-0.15^{*}$ & 1 & & & \\
\hline$\Delta$ Unemployment & $0.27^{*}$ & 0.09 & -0.10 & 0.01 & $0.20 *$ & $-0.22 *$ & 1 & & \\
\hline$\Delta$ Interest rate & $0.21 *$ & $-0.13 *$ & -0.02 & 0.00 & 0.04 & $0.13 *$ & $0.13 *$ & 1 & \\
\hline Government changes & -0.02 & -0.03 & -0.05 & 0.09 & 0.12 & 0.03 & 0.05 & $0.14 *$ & 1 \\
\hline
\end{tabular}

Note: $N=269$.

"P $<0.05$. 